\title{
Lordship and Sovereignty in the Territories of the English Crown: subkingship and its implications, 1300-1600
}

Conventional typologies of lordship and its relationship with royal power in the territories of the English crown emphasise the precocious distinctiveness of royal power as against noble lordship, with the latter consequentially bound by an essentially restrictive territorialised model. With the decline of pan-British activity after the difficult years 1296-1333, the focus of most English historians of lordship is on a primarily English territorialised lordship which, because of a fragmentation of holdings, might be powerful but never constitute an overwhelming nexus. Writing in the shadow of Bruce McFarlane, they have concentrated on processes of exclusion, definition and stratification in the nobility in the late middle ages. The vista of English royal authority, formal and informal, is also constantly spread before us, as a clearly distinctive alternative to noble lordship. The consequence has therefore been an emphasis on overlapping patterns of interest, the importance of noble patronage and household, and the significance of interactions with that ever-growing English royal authority. ${ }^{1}$ Rees Davies in his last, unfinished book, on Lords and Lordship in the long fourteenth century, however, reminded us that lordship was potentially more complex and extensive than that. His prime points of reference were marcher lords: their lordship, and that of some in Ireland, "approximated (or could do so) more closely to royal lordship than we

\footnotetext{
${ }^{1}$ Particularly important contributions of this type have been Scott L. Waugh, The Lordship of England: Royal Wardships and Marriages in English Society and Politics, 1217-1327 (Princeton, NJ, 1988); J. M. W. Bean, From Lord to Patron: Lordship in Late Medieval England (Manchester, 1989), esp. 231-7; P. R. Coss, "Bastard Feudalism Revised," Past \& Present 125 (Nov. 1989): 27-64; David Crouch “Debate: Bastard Feudalism Revised," Past \& Present 131 (May 1991): 165-77; Michael Hicks, Bastard Feudalism (London, 1995). I am grateful for the assistance of colleagues and friends who have provided advice during the development of this paper, and especially the participants in the symposium 'Lords and Lordship in the British Isles' held at St Andrews in Sept 2015, convened by Dr Alison Cathcart and Prof. Michael Brown, and also to the insightful comments of reviewers for this Journal.
} 
sometimes care to acknowledge". ${ }^{2}$ This paper is intended to explore the continuum which Davies proposed. In place of the neat, clean hierarchy subordinated to a growing royal authority it will consider the potential complexity of manifestations of sovereignty in these territories. In particular, it will assess the use of royal titles by people other than the English king, and associated ceremonial and issues such as forms of dating. It will also consider some practical manifestations of "sovereign" power, in judicial and fiscal rights, and relations between princes; and the capacity to exclude the intervention of others. It responds to prompts from the recent historiography of the jurisdictional complexity of England and other early modern states. ${ }^{3}$ Borrowing a term which has been applied elsewhere for political systems in which sovereignty is not held by one individual in absolute form, but shared in a more diffuse manner, ${ }^{4}$ it will argue for the continuing reality of subkingship, whether with royal title or a lordly one associated with the most extensive powers, in the British Isles through the late medieval and early modern period.

The clearest evidence for such a subkingship is to be found in the case of the kingship, or lordship, of the Isle of Man, in material relevant to the fourteenth and fifteenth centuries. That

\footnotetext{
${ }^{2}$ R. R. Davies, Lords and Lordship in the British Isles in the Later Middle Ages (Oxford, 2009), esp. 18, 160-1, 172, 176 for "royal" lordship with a strongly communal and tributory character.
}

${ }^{3}$ Tom Johnson, Law in Common: Legal Cultures in Late-Medieval England (Oxford, 2019); R. A. Houston, "People, Space, and Law in Late Medieval and Early Modern Britain and Ireland," Past \& Present 230 (2016): 47-89; Richard Jeffrey Ross and Lauren A. Benton, eds., Legal Pluralism and Empires, 1500-1850 (New York: New York University Press, 2013); Anthony Musson, "Jurisdictional Complexity: The Survival of Private Jurisdictions in England," in The Laws' Many Bodies: Studies in Legal Hybridity and Jurisdictional Complexity, c1600-1900, ed. Seán Patrick Donlan and Dirk Heirbaut (Berlin, 2015), 109-26.

${ }^{4}$ James Campbell, Bede's Reges and Principes (The Jarrow Lecture; Jarrow, 1979). In the Anglo-Saxon context, Campbell writes of men who at the same time might have been referred to by different writers as 'rex, subregulus, princeps, dux, praefectus and comes', who were subordinated to greater reges, but where there was 'something about their status and functions which made them in some ways similar to reges' (p. 7). 
evidence illustrates the royal status and power of the island's lord in the eyes of audiences locally and further afield. About 32 miles long, and at its widest 14 miles across, the island covers just over 220 square miles. It lies in the Irish Sea between Ireland, Scotland, Wales and England, where it is about 35 miles from the coast at St Bees in the historic county of Cumberland, about the same distance from the coast of Ulster near Downpatrick, but only 16 miles from Burrow Head on the Machar peninsula in south-west Scotland, while it is less than 50 miles from the nearest point in Wales, the Isle of Anglesey (Ynys Môn). The Isle of Man was Viking, then Scottish territory which had been the subject of English interest for some decades before it was taken by Edward III during the 1340s. Edward granted the island to William Montacute, earl of Salisbury; his son sold the island to William le Scrope, earl of Wiltshire. The revolution of 1399 resulted in the island being granted to the earl of Northumberland, before his treason led to grants in 1405-6 to the first of a succession of members of the Stanley family, Sir John (d. 1414). ${ }^{5}$

The ability of these rulers to appoint to the bishopric of Man was clearly associated with sovereign rights at several points. In 1399, Henry Percy received the island with all appurtenances, “simul cum Patronatu Episcopatus dictae Insulae de Man”, and again in 1406, for Sir John Stanley the same formula was used. ${ }^{6}$ The lord levied customs; he was also entitled to all "Choice Wine". He received treasure trove, deodands, waifs and strays; goods of excommunicates and of aliens who had died without swearing allegiance, and of strangers

\footnotetext{
${ }^{5}$ A New History of the Isle of Man, III: The Medieval Period, 1000-1406, ed. Seán Duffy and Harold Mytum (Liverpool, 2015).

${ }^{6}$ Calendar of Patent Rolls, 1399-1401, 27, 171; Calendar of Patent Rolls, 1405-1408, 201-2 (grant 6 Apr 1406, printed in Monumenta de Insula Manniae, or, A Collection of National Documents Relating to the Isle of Man, ed. J. R. Oliver, Manx Soc., 4, 7, 9 (Douglas, 18602), ii. 237, with the incorrect date of 19 Oct 1406).
} 
who were found guilty of manslaughter; purveyance and pre-emption; and he had exclusive rights of hunting in forests and warrens. He issued ordinances, in consultation with his council and the deemsters (judges) and Keys (jurymen and lawgivers) in a manner which came to take the form of a legislative process in the sitting of Tynwald. His were a full range of courts, with a complete set of jurisdictions and sanctions, the Court of General Gaol Delivery being the superior court of criminal justice, and the Chancery Court the superior civil court, and the lord had powers to impose, mitigate and pardon a death penalty. His Admiralty is especially worthy of note, marked by the lord's rights to royal fish and to the profits of wreck. All were signs of royal power. ${ }^{7}$

The English courts could not touch the island, and this applied even to those which expressed the power of the crown to respond to the petition of the subject, in spite of jurisdictional boundaries, initially King's Bench, later the medieval Chancery, and even ultimately Parliament in its function as a high court. The English crown's response to petitioners might have been influential in shaping the development of some jurisdictions elsewhere, but the Isle of Man was not one of them. ${ }^{8}$

\footnotetext{
${ }^{7}$ The lord's powers are conveniently described in J. R. Dickinson, The Lordship of Man under the Stanleys: Government and Economy in the Isle of Man, 1580-1704, Chetham Soc., $3^{\text {rd }}$ ser., 41 (1996), ch. 1.

${ }^{8}$ Nicholas Pronay, "The Chancellor, the Chancery and the Council at the end of the Fifteenth Century," in British Government and Administration: Studies Presented to S. B. Chrimes, ed. H. Hearder and H. R. Loyn (Cardiff, 1974), 87-103, esp. 92-100; Franz Metzger, “The Last Phase of the Medieval Chancery," in Law-Making and Law-Makers in British History, ed.
} Alan Harding (London, 1980), 79-89 ; Tim Thornton, Cheshire and the Tudor State, 1480- 
A distinctive position in foreign relations on the part of the lord was recognised by the English crown. In 1389x93 provision for redress in relation to truces with France, Scotland and elsewhere acknowledged the responsibility of the earl of Salisbury for the lordship of Man. ${ }^{9}$ The lordship was treated distinctly in orders for proclamation of a truce in 1414 and 1416, and in the truce of Tours (1444) and its successors under Henry VI, Thomas Stanley as lord of Man was relatively unusual, with only the royal dukes of York and Norfolk, in being consistently identified as confederate of the king of England. ${ }^{10}$

It was not just the powers of the lord which mattered, however, it was how he or she was described and his or her title. Late medieval English chroniclers record the use of the royal title and associated paraphernalia in connection with the Isle of Man. The usually reliable

1560 (Woodbridge, 2000), 103-10, esp. 109-10; Guilhem Pépin, "Petitions from Gascony: Testimonies of a Special Relationship," in Medieval Petitions: Grace and Grievance, ed. W. Mark Ormrod, Gwilym Dodd and Anthony Musson (Woodbridge, 2009), 120-34, at 121-3, 132-4; Gwilym Dodd, "Parliamentary Petitions? The Origins and Provenance of the 'Ancient Petitions' (SC8) in the National Archives," in ibid., 12-46, at 19; Paul Brand, "Petitions and Parliament in the Reign of Edward I," in Parchment and People: Parliament in the Middle Ages, ed. L. Clark (Edinburgh, 2004), 14-38; J. H. Baker, An Introduction to English Legal History (4 ${ }^{\text {th }}$ edn, London and Dayton, OH, 2002), 137, 207-8.

${ }^{9}$ TNA, SC 1/63/279 (Calendar of Documents Relating to Scotland, v: Supplementary, A.D. 1108-1516, ed. Grant G. Simpson and James D. Galbraith (Edinburgh, 1986), \#868).

${ }^{10}$ Calendar of Close Rolls, 1413-19, 108, 369; Calendar of Close Rolls, 1441-7, 233, 366;

Calendar of Close Rolls, 1447-54, 37. In the 1440s, some Manx at least were treated as ‘alien' under English subsidy legislation: “England's Immigrants 1330-1550,” accessed February 14, 2020, https://www.englandsimmigrants.com/. 
Geoffrey le Baker tells us that William de Montacute, first earl of Salisbury was crowned king of Man in the early 1340s. ${ }^{11}$ Then, half a century later and prompted by recent and contemporary transactions in relation to the kingship, as it was sold by the second William Montacute earl of Salisbury to William le Scrope, and then passed through the hands of the Percies before being granted to the Stanley family, Thomas of Walsingham gave some prominence to the Manx kingship and to Man as a kingdom. One of the St Albans chroniclers who made that tradition the nearest thing to an official historiography which England possessed, Walsingham stated the case clearly: "rex uocatur, cui eciam fas est corona aurea coronari". ${ }^{12}$ His successors such as John Capgrave continued this tradition. ${ }^{13}$ Other informed English observers also relied on the concept of kingship: William Worcester in the late fifteenth century stated that the castle of "Fotrey", meaning Fouldry Castle on Piel Island,

${ }^{11}$ Chronicon Galfridi le Baker de Swynebroke, ed. E. M. Thompson (Oxford, 1889), 75, 247; The Chronicle of Geoffrey Le Baker of Swinbrook, trans. David Preest; introduction and notes by Richard Barber (Woodbridge, 2012), 66; W. M. Ormrod, "Man under the Montacutes, 1333-92," in A New History of the Isle of Man, vol. III: The Medieval Period 1000-1406, ed. Sean Duffy and Harold Mytum (Liverpool, 2015), 151-69, at 158.

${ }^{12}$ The St Albans Chronicle: The Chronica Maiora of Thomas Walsingham, ed. John Taylor, Wendy R. Childs, and Leslie Watkiss (2 vols, Oxford, 2003-10), i. 940; cf. references to regnum Eubonie at ii. 158, 392.

${ }^{13}$ John Capgrave, Abbreuiacion of Cronicles, ed. Peter J. Lucas, Early English Text Soc., os 285 (1983): 202 (the sale of Man, "with [th]e crowne" "for he [th] at is lord of [th]is yle may were a crowne"). 
belonged to the king of Man: pertinent Regi de Man. ${ }^{14}$ It was even possible for the English king's representatives to refer directly to a king of Man, as at the Council of Constance when they were cataloguing the kings who were subject to him. ${ }^{15}$

On the island itself, the late medieval administration of its rulers used the language of kingship freely. On Sir John Stanley's first visit to the island as its ruler, he was described as being in "Royal array, as a King ought to do by the Prerogatives and Royalties of the Land of Man”. He sat on Tynwald Hill on a chair covered with red "Royall Cloath and Cushions", with a sword borne upright before him. ${ }^{16}$ In 1422, the court of Sir John Stanley (d. 1437) saw a proclamation of his title: "by the Grace of God, King of Mann and Th'isles"; later in the decade action was taken against a "Traytor to the King of Mann by the Laws of Mann". ${ }^{17}$

The title of king was commonly used in the more routine business of the island's courts by his officers. The earliest surviving extensive records open with a description of the officers present in court on 28 November 1496 that describes deemster John More as justice domini Regis. At the end of the sequence of courts begun on 8 May 1497, in the Gaol Delivery held

\footnotetext{
${ }^{14}$ William Worcester, Itineraries, ed. John H. Harvey (Oxford, 1969), 135. The castle in practice belonged to the abbot of Furness.

${ }^{15}$ Giovanni Domenico Mansi, Sacrorum conciliorum nova et amplissima collectio (31 vols, Florence and Venice, 1759-98), xxvii 1062.

${ }^{16}$ The Lex Scripta of the Isle of Man: Comprehending the Ancient Ordinances and Statute Laws from the Earliest to the Present Date (Douglas; London, 1819), 1-5, at 1.

${ }^{17}$ Lex Scripta, 5-8, 12-13; "Traitors to the King of Man: Impeachment of the Household Officers in 1428," Journal of the Manx Museum 5 (1965): 51-4, at 52.
} 
at Castle Rushen on 22 May, an even more explicit formula appears: justices domini Regis Mannie. $^{18}$

Even when the title used for the island's ruler is "lord", there are often signs that this is a royal lordship. Papal letters of 1392 for William le Scrope regarding the building of a castle on Patricksholm (Peel), and for alms for the cathedral of the diocese, describe him as lord, but lord of the kingdom of Man and the Isles. ${ }^{19}$ Methods of dating, placing ourselves in time, are also potent signs of royal power, and the $1417 / 18$ court in the island was dated by anno domini and "Regalitat' Dni Mann quarto". ${ }^{20}$ Even if the regnal year of the king of Man was not used, the Stanley lords might pointedly omit the regnal year of the English king and use anno domini alone instead, as was the practice still early in the sixteenth century and even in documents issued in England - this was tantamount to asserting that they had royal authority

${ }^{18}$ Books of Pleas ("Lib. Plit"), unnumbered and unfoliated, M[anx] M[useum and] L[ibrary], [Douglas.]

${ }^{19}$ Calendar of Entries in the Papal Registers Relating to Great Britain and Ireland. Papal

Letters, iv: A.D. 1362-1404, ed. W. H. Bliss and J. A. Twemlow (London, 1902), 432-3.

${ }^{20}$ MS 510C; MS 09864/2 (formerly GR 1/2), MML (Monumenta, iii. 10-12). For the 1417 visit, see A. W. Moore, A History of the Isle of Man (2 vols, London, 1900), i. 212. 
under god in the island in any case. ${ }^{21}$ The Stanleys referred to the people of Man as their subjects. $^{22}$

Manx language sources are few and far between, limiting our ability to assess whether monoglot Manx speakers saw their rulers as kings. The "Traditionary Ballad", however, probably written between 1485 and the death of the first earl of Derby in 1504, implies that the title Ree was then the accustomed manner of address to the lord. This clearly meant "king" in as full a form as the title of the monarch of England, since the word was also used for him. Orry (meaning Godred Crovan, d. 1095) was the "first ... to be king in the iland" (“Ree er yn Ellan") - a passage suggesting a very self-conscious awareness of the difference the title made to the standing of the island's ruler. The ballad emphasises the legitimacy of the transition from the Viking dynasties to the lordship of William de Montacute - William

${ }^{21}$ In 1511, a commission to the lieutenant in the island, constituting Dr Bradshaw chancellor and Mr John Watt archdeacon commissioners to hear and examine a matter between the abbot of Furness and the abbot of Rushen and between the bishop and the prior of Whithorn used the form mdxi in roman style (my amendment from mdxlmo which might otherwise be read as 1540, but cannot be because of the mention of the abbot and of Thomas, earl of Derby): “Unpublished Documents," Journal of the Manx Museum 2, no. 27 (1931): 17-21, at 21.

${ }^{22}$ Correspondence of Edward, Third Earl of Derby, during the Years 24 to 31 Henry VIII, ed. T. Northcote Toller, Chetham Soc., $2^{\text {nd }}$ ser., 19 (1890), 120. 
himself, the ballad affirms, "was king of Man”. The Stanleys' arrival is greeted by the loyalist sentiment: "one king after another preserving us from danger". ${ }^{23}$

Whether in England or in Man itself, in the fourteenth and fifteenth centuries the idea of a king of Man, or at the least a lord associated with kingly powers, was widespread and widely accepted.

How isolated an example is that from the Isle of Man? There were in practice many parallels elsewhere in these islands that represented a form of sovereignty under the overall control of the English crown, in which extensive powers of lordship were associated with use of the title "lord" that had more than the usual resonance to it - or even a title of "king".

The most extreme example, but one which should be taken a little more seriously in light of the Manx evidence, lies in the Isle of Wight. It may originally have been home to an AngloSaxon royal dynasty, but there is nothing clearly royal about the title to the island in the years immediately after the Norman Conquest. On the other hand, the title of "lord" was associated with Wight before it was appropriated by Edward I, notably by its last and most powerful de Revières lord, Isabella de Fortibus, through to the 1290s, and there was a growing tradition that the island was held as freely as the king held England. ${ }^{24}$ In 1382 William de Montacute,

${ }^{23}$ R. L. Thomson, “The Manx Traditionary Ballad,” Études Celtiques 9, fasc. 2 (1961): 52148; 10, fasc. 2 (1962): 60-87, at 63-4 (Ree Hocsyn); 544, 545, 65, 66, 67, 74, 75 (Manx kings).

${ }^{24}$ N. Denholm-Young, "Edward I and the Sale of the Isle of Wight," English Historical Review xliv, no. 175 (July 1929): 433-8; N. Denholm-Young, "The Yorkshire Estates of 
second earl of Salisbury and lord of Man, was made keeper of the island for a year, extended in 1385 to a grant of the lordship and keeping for life, with unusually extensive rights. ${ }^{25}$ By February 1382/3 he was using the title "Seignior de Man \& de l'Isle de Wight", ${ }^{26}$ a juxtaposition implying some equivalence. By the 1440s further steps towards formal subkingship may have been taken: the Tewkesbury chronicle, the Clare/Despenser family annals, described how Henry Beauchamp was crowned king of the Isle of Wight by Henry VI in 1444. "[C]oronatus est in Regem de Wyth Manu Regia”. A little later, we come to the death

Isabella de Fortibus," Yorkshire Archaeological Journal 31, no. 4 (1934): 389-420; N.

Denholm-Young, Seignorial Administration in England (Oxford, 1937), 99-119. Egerton MS 3667, British Library; The Cartulary of Carisbrooke Priory, ed. S. F. Hockey ([Isle of Wight], 1981), 172-3, includes a memorandum on the descent of the island from William Fitz Osbern; an English $16^{\text {th }}$-century version is SAL/MS/254, Society of Antiquaries, London. There are $16^{\text {th }}$-century excerpts in Lansdowne MS 229, fol. 116, British Library (compiled by, and in the hand of, Robert Glover (1543/4-88), Somerset Herald, 1573), and identical ones in MS lat. Hist. b. 3, British Library, which are copies from 1710-31, from a transcript made during Elizabeth's reign by Francis Harris. Both he and John Kingsmill, perhaps the Elizabethan JP (whose version was owned by Mrs Prescott in 1871, Historical Manuscripts Commission (hereafter HMC), Second Report (London, 1871), 98), took this from Black Book which was shown by Robert Glover to William Camden, who made extracts in Lansdowne MS 229, British Library; see Times Literary Supplement, 23 Feb 1928, p. 131. ${ }^{25}$ Calendar of Patent Rolls 1381-5, 103; Calendar of Patent Rolls 1385-9, 16 (the lordship, as fully as the king had the same, including e.g. chattels of felons and fugitives, and wreck of the sea).

${ }^{26}$ John Selden, Titles of Honor ( $3^{\text {rd }}$ edn, London, 1672), 25. 
of Henry: "obiit autem dominus Henricus ... Rex de insulis le wythe". ${ }^{27}$ In this light it is perhaps understandable that Richard duke of York felt so sharply the loss of the island, to which his aunt Philippa, widow of Edward of Langley, duke of York, had still proudly laid claim on her death in 1431, as "dame de l'ysle de Wyght", when it was resumed and given to Edmund, duke of Somerset in 1452, confirmed to his widow Eleanor in 1456, and granted to the new duke, Henry, in $1457 .^{28}$

Henry Beauchamp takes us to another possible instance of fifteenth-century sub-kingship, in the Channel Islands. The Tewkesbury Chronicle, in marking his death, refers to him as king of Wight, as we have just seen, but goes further, describing him as "rex de insulis Wight, et Gardsay, et Jardsey". ${ }^{29}$ For Jersey and Guernsey this is an admittedly isolated instance, but the bailiwicks do show the continuing potential for the power of lordship, in a context in which judicial and other administration became almost entirely autonomous after the midfourteenth century. ${ }^{30}$ After the grant of the lordship of the isles to the duke of Bedford in

${ }^{27}$ MS Top. Glouc. d. 2, Bodleian Library, Oxford, fols. 32v, 35 (printed William Dugdale, Monasticon Anglicanum (London, 1655), 159).

${ }^{28}$ Richard Gough, A Collection of all the Wills, now known to be Extant, of the Kings and Queens of England, Princes and Princesses of Wales, and Every Branch of the Royal Blood (London, 1780), 224; P. A. Johnson, Duke Richard of York, 1411-1460 (Oxford, 1988), 1201, 175; Calendar of Patent Rolls 1452-61, 18, 291, 390-1.

${ }^{29}$ MS Top. Glouc. d. 2, Bodleian Library, Oxford, fol. 35 (printed Dugdale, Monasticon Anglicanum, 159).

${ }^{30}$ J. H. Le Patourel, The Medieval Administration of the Channel Islands, 1199-1399 (London, 1937); Tim Thornton, The Channel Islands, 1370-1640: Between England and 
1415, we have, for example, in 1417 a contrat issued in Jersey describing Thomas Daniel as bailiff under the "tresnoble \& puissant prince monss' le duc de Bedefford Comite de Rychemund \& de Kendall Conetable dengleterre \& ss'r des yslles”. A similar formula was used for Bedford's successor in the lordship, his brother Gloucester, after his grant in $1437 .{ }^{31}$ The sense of the independence of the lordship is accentuated by the manner in which, during times of uncertainty in the mid- to late 1450 s, reference to all external authority was dropped, with the Jersey bailiff John Poingdestre referred to simply as "ballif en lisle de gersei". ${ }^{32}$

Another parallel, in the Irish Sea, was provided by Lundy - and again a connection through the Montacutes appears. William acquired Lundy in 1332, just a year before Man. ${ }^{33}$ Here the Normandy (Woodbridge, 2012); idem, The Channel Islands and the Courts of Westminster from the Fourteenth to the Sixteenth Centuries (St Helier, 2017).

${ }^{31}$ Proceedings and Ordinances of the Privy Council of England, ed. Harris Nicolas (7 vols, London, 1834-7), v. 5 (from BL, Add. MSS. 4607, art. 130); TNA, C 76/119, m. 5 (Thomas Carte, Catalogue des rolles Gascons, Normans et Français, conservés dans les archives de la Tour de Londres (2 vols, Londres [i.e. Paris], 1743), ii. 290); The Forty-eighth Annual Report of the Deputy Keeper of the Public Records (London, 1887), appendix, 317); for an instance of the use of their titles, see Cartulaire des îsles normandes: recueil de documents concernant l'histoire de ces îles conservés aux Archives du Département de la Manche et du Calvados, de la Bibliothèque nationale, du Bureau des Rôles, du Château de Warwick, etc. (Jersey, 1918-24), 353, item 275.

${ }^{32}$ Lord Coutanche Library, Société Jersiaise, de St. Martin Contrat, No. 22 (2 November 1456); 2 unnumbered contrats at Lord Coutanche Library, Société Jersiaise, in file of "Old Contrats 1300s and 1400s" (2 April 1457; 11 April 1458).

${ }^{33}$ Calendar of Patent Rolls, 1330-4, 364. 
title that the island carried at that time is not clear, although it already had significantly extensive rights and a distinctive position associated with it, for example permitting its separate treatment in the Anglo-Scottish treaties of 1484, 1488, and $1497 .{ }^{34}$ Nearly three hundred years later, a pirate, Thomas Salkeld, chose to call himself king of Lundy in 1610, and as late as the English Civil War, a royalist captain writing to Lord Saye and Sele described him as "petty Prince" of the "preety Island" ${ }^{35}$ This points up the significance of islands, however small, in being able to sustain royal titles. English political culture and the political culture of the islands themselves recognised a completeness to the political community of an island.

Also significant is the continuing existence of the title of the Lordship of the Isles - the Hebridean portion of the old Kingdom of Man and Isles. This lordship of the Isles was a title which the Macdonalds continued to bear until 1493 when they were dispossessed by James

\footnotetext{
${ }^{34}$ Stephen Boardman, The Campbells, 1250-1513 (Edinburgh, 2006), 228.

${ }^{35} \mathrm{HMC}$, Calendar of the Manuscripts of the Most Honourable the Marquess of Salisbury (23 vols, London, 1883-1973), xxi. 209-10 (27 Mar 1610 - John Tanner and Thomas Clarke report Salkeld wants pardon and Lundy "for his inheritance”), 212-15; Calendar of State Papers Domestic 1603-1610, 601 (vol liii. 100: deposition of William Young; Salkeld "called himself King of it"); M. M. Oppenheim, The Maritime History of Devon (Exeter, 1968), 56; A. F. Langham, The Island of Lundy (Stroud, 1994), 43. Cf. Sir John Eliot's extensive advice on the right to fortify the island: John Forster, Sir John Eliot: A Biography, 1590-1632 (2 vols, London, 1864), ii. 626-8; Roger Granville, The History of the Granville Family: Traced back to Rollo, First Duke of Normandy (Exeter, 1895), 174-81.
} 
IV. ${ }^{36}$ It is, however, striking that the Stanleys frequently referred to themselves not simply as king or indeed lord of Man, but as king or lord of Man and the Isles: they did so in the documentation of legal proceedings of 1422, for example. On 27 May 1574, the royal licence for Henry earl of Derby to enter his lands called Edward his deceased father Lord of Man and the Isles. ${ }^{37}$ As Alexander Grant has noted of the Scottish lordship of the isles, the word "dominus" is a "notoriously difficult word to translate". He points out that before 1476 it was uniformly used as a translation for the Gaelic Rí, which can mean king. We have already seen that the Manx equivalent Ree seems to have stood for king in the context of late fifteenthcentury Man.

There were also the Marcher lordships, as Rees Davies himself pointed out - William de Montacute had obtained Denbigh in 1331, just a couple of years before the grant of the Isle of Man, and so some of the possible parallels must have seemed obvious to him. ${ }^{38}$ These marcher lords possessed regalities by right of conquest from the native Welsh princes, not grant from the crown. The parallel, particularly with Man before 1399, was very strong. Of course the Welsh marcher lordships were abolished under Henry VIII, but not until 1536, and

\footnotetext{
${ }^{36}$ Alexander Grant, "Scotland's 'Celtic Fringe' in the Late Middle Ages: The Macdonald Lords of the Isles and the Kingdom of Scotland," in The British Isles, 1100-1500:
}

Comparisons, Contrasts and Connections, ed. R. R. Davies (Edinburgh, 1988), 118-41. See also on these titles W. McLeod, "Rí Innsi Gall, Rí Fionnghall, Ceannas nan Gàidheal: Sovereignty and Rhetoric in the Late Medieval Hebrides," Cambrian Medieval Celtic Studies xliii (2002), 25-48

${ }^{37}$ Lex Scripta, 5-6, 12; Calendar of Patent Rolls, 1572-5, 264, item 1425.

${ }^{38}$ Letters patent of William de Montacute as earl of Salisbury and Lord of Man and Denbigh: Bagot Bachymbyd deeds, National Library of Wales, Aberystwyth, 2 (5 Aug 1355). 
even then they retained some quasi royal rights, including that of taxation. ${ }^{39}$ While the status of other extremely powerful lordships differed, having been granted by the English crown and to a greater or lesser extent shaped in their creation by it (rather than conquered by the lords themselves, as in the case of the Welsh lordships), they should nonetheless be taken into account in this survey, as they provide other points along the spectrum of lordship alluded to by Davies. The bishop of Durham possessed very extensive rights over his palatinate, with a mint operating from the twelfth century and justices of assize and of the peace appointed under his own seal, as well as his own sheriff, coroners and other officers, for example; the palatine county of Lancaster was created for Henry of Grosmont, first duke of Lancaster, in 1351, with a nearly equivalent set of rights and privileges that made the duke's position "entirely exceptional" and with "as much resemblance to the contemporary French seigneurie as to any other English lordship". ${ }^{40}$

${ }^{39}$ R. R. Davies, Lordship and Society in the March of Wales, 1282-1400 (Oxford, 1978); T. B. Pugh, The Middle Ages: The Marcher Lordships of Glamorgan and Morgannwg and Gower and Kilvey from the Norman Conquest to the Act of Union of England and Wales (Glamorgan County History, Vol. 3) (Cardiff, 1971); The Marcher Lordships of South Wales, 1415-1536: Select Documents, ed. T. B. Pugh, Board of Celtic Studies, University of Wales, History and Law Series, 4 (Cardiff, 1963).

${ }^{40}$ Christian D. Liddy, The Bishopric of Durham in the Late Middle Ages: Lordship, Community and the Cult of St Cuthbert (Cambridge, 2012), esp. ch. 3-5; Tim Thornton, "Fifteenth-century Durham and the Problem of Provincial Liberties in England and the Wider Territories of the English Crown," Transactions of the Royal Historical Society $6^{\text {th }}$ ser., 11 (2001): 83-100; Simon Walker, The Lancastrian Affinity, 1361-1399 (Oxford, 1990), 141-81 (quotations 141, 143); Robert Somerville, History of the Duchy of Lancaster (2 vols, London, 1953-70), i: 1265-1603. Beyond this, the marches toward Scotland and north of England offer other examples of powerful lordship where the king's writ did not run and with distinctive identity: e.g. A. J. Pollard, North-Eastern England during the Wars of the Roses: Lay Society, War and Politics, 1450-1500 (Oxford, 1990), esp. ch. 6; Andy King, "The Anglo-Scottish Marches and the Perception of the North in Fifteenth-Century England," Northern History 49, no. 1 (Mar. 2012): 37-50. 
Paradoxically, there are also the examples of allegations of ambition for kingship, or of potential royal generosity, which did not in practice bear fruit. These instances should be read in the light of the evidence already offered and treated as potentially more serious than has often been the case. But in themselves they also added to the climate in which the use of royal titles was more widespread than has been accepted. The most prominent examples are those relating to Ireland. Under Richard II, the king's creation of Robert de Vere as duke of Ireland in October 1386, enhancing his former palatine powers as marquess to a position where Richard retained only liege homage for the lordship, encouraged some to believe de Vere would be made king there. Later in the reign it was believed a similar grant of kingship in Ireland was intended for the duke of Surrey. ${ }^{41}$ Then under Henry VIII, there was the possibility that his illegitimate son Henry Fitzroy, duke of Richmond and Somerset, might be made king of Ireland, where he was for a time lord lieutenant. ${ }^{42}$ On a similar theme, some of

${ }^{41}$ St Albans Chronicle, ed. Taylor et al., i. 798-9; The Chronicle of Adam Usk, 1377-1421, ed. C. Given-Wilson (Oxford, 1997), 76-7 (Richard's intention to make his nephew king of Ireland "apud Dublineam cum magna mundi uangloria in regem coronare Hibern"” - reported in relation to 1399; no other chronicler reports this).

${ }^{42}$ Calendar of Letters, Despatches, and State Papers Relating to the Negotiations between England and Spain, ed. G. A. Bergenroth, P. de Gayangos, M. A. S. Hume, and R. Tyler (16 vols, London, 1862-99), iii/2. 632; Letters and Papers, Foreign and Domestic, of the Reign of Henry VIII, ed. J. S. Brewer, J. Gairdner, and R. H. Brodie (21 vols in 37, London, 18641920), iv. 3028; Beverley A. Murphy, Bastard Prince: Henry VIII’s Lost Son (Stroud, 2001), 87-8, 115-16. 
the concern about Piers Gaveston under Edward II arose from the belief that the king intended to make him a 'princely' grant of the royal earldom of Cornwall. ${ }^{43}$

A final context is provided by the position of the heir to the English throne. One element of their importance here lies in the way their lordship drew on an element of the sovereignty of the English crown that was unavoidably present in their person as heir. This was more explicitly acknowledged in some cases than in others, usually because of circumstances of dynastic insecurity, such as when Henry IV had the position of his eldest son recognised in parliament at his accession. ${ }^{44}$ The wider significance of these princes also lies in part in the fact that in their territorial associations with Wales, Cheshire and Cornwall they could draw on the power of the western parts of Britain; and that power, in their hands, was still significant, partly because of the very difference that was enshrined through the special

${ }^{43}$ Pierre Chaplais, Pierre Gaveston: Edward II's Adoptive Brother (Oxford, 1994), 27, 30-1, 34. Vita Edwardi Secvndi: The Life of Edward the Second, ed. Wendy R. Childs (Oxford, 2005), 4-5, 28-9; Johannis de Trokelowe et Henrici de Blaneforde, monachorum S. Albani, necnon quorundam anonymorum Chronica et annales, regnantibus Henrico Tertio, Edwardo Primo, Edwardo Secundo, Ricardo Secundo, et Henrico Quarto, ed. Henry Thomas Riley, Rolls Ser. 28iii (London, 1866), 65 (specialiter spectat ad coronam).

${ }^{44}$ The Parliament Rolls of Medieval England, 1275-1504, ed. C. Given-Wilson et al. (16 vols, Woodbridge, 2005), viii. 33; P. McNiven, "Legitimacy and Consent: Henry IV and the Lancastrian Title, 1399-1406," Medieval Studies xliv (1982): 470-88, at 481-2; C. Given Wilson, "Legitimation, Designation and Succession to the Throne in Fourteenth-century England," in Building Legitimacy: Political Discourses and Forms of Legitimacy in Medieval Societies, ed. Isabel Alfonso, Hugh Kennedy, and Julio Escalona (Leiden, Boston, 2004), 89106 , at 103-4. 
position of the prince. Those resources could be material - with an extensive and geographically-focussed set of fiscal,legal and other rights ${ }^{45}$ - and through the link to the "British History" they also came in the form of a powerful stock of traditions and ideas about the past. ${ }^{46}$

It can therefore be argued that these islands were in the late middle ages home to a group of lords whose powers and standing took them to the level where they warranted the title of "lord" with many resonances of sovereignty, and sometimes even that of "king" itself, reflecting many of the powers of royalty. It must be acknowledged that such an account stands in the face of the historiography of the past two centuries, and especially of a historiography describing the final death of sub-kingship in the territories of the English crown. That historiography has tended to focus on the Isle of Man, and events in 1504. Virtually all historians of the island have been convinced of the surrender of the royal title in that year. R. H. Kinvig described the surrender of the title in 1504, on the death of the first earl and the accession of the second earl of Derby, following A. W. Moore in his major history published in 1900. Most recently Roger Dickinson pushed the date of the end of the

\footnotetext{
${ }^{45}$ John Hatcher, Rural Economy and Society in the Duchy of Cornwall, 1300-1500 (London, 1970); Michael J. Bennett, Community, Class and Careerism: Cheshire and Lancashire Society in the Age of Sir Gawain and the Green Knight (Cambridge, 1983), 204-35; The Victoria History of the Counties of England: The County of Chester, ed. Brian E. Harris, A. T. Thacker and C. P. Lewis (London, 1979-), ii. 9-35; Ralph A. Griffiths, The Principality of Wales in the Later Middle Ages: The Structure and Personnel of Government, South Wales 12771536 (Cardiff, 2018).

${ }^{46}$ Tim Thornton, "Dynasty and Territory in the Early Modern Period: The Princes of Wales and their Western British Inheritance," Welsh History Review 20, no. 1 (June 2000): 1-33; P. R. Roberts, “The Union with England and the Identity of 'Anglican' Wales," Transactions of the Royal Historical Society $5^{\text {th }}$ ser., 22 (1972): 49-70, esp. 66-70.
} 
Manx kingship even earlier, stating that Sir William Montacute dropped the title when he took control of the island in the $1330 \mathrm{~s} .{ }^{47}$

A belief in the final demise of sub-kingship around this time is also true of the wider historiography of England and the British Isles in general. Sir Geoffrey Elton provides an eminent and stark example of belief in the inevitability of centralisation and the imposition of uniform royal sovereignty. While Elton generally accepted that Henry VII's main challenge was to provide strong leadership, not reshape social alliances, he believed that there was "only one problem [that] could not be solved by mere restoration or revival, and that was the problem of franchises and feudal courts": he writes of how popular support enabled "Tudor kings to ride roughshod over the petty kingdoms". It was the achievement of the Tudors, and, for Elton, a major element of Thomas Cromwell's "revolution in government", that they took a country which, though centralised, suffered from the limited disunity which did exist, and completed its unification. ${ }^{48}$ Elton's approach to this subject has been challenged, but others adopting different perspectives on centralisation in the whole of the British Isles still often draw on the Manx example. Ralph Griffiths, for instance, relies specifically on the fact that

${ }^{47}$ R. H. Kinvig, The Isle of Man: A Social, Cultural and Political History (3rd edn; Liverpool, 1975; originally titled A History of the Isle of Man (1944)), 96-7; A. W. Moore, History of the Isle of Man (2 vols, London, 1900), i. 218; Dickinson, Lordship of Man, 15-16. ${ }^{48}$ G. R. Elton, England under the Tudors (London, 1955, reprinted 1967), 4, 14-16, 175-80. 
Henry VII made the earl of Derby surrender his title of king of Man in 1504 as a sign of tightening royal control in the non-English territories of the crown. ${ }^{49}$

The problem with all these statements about the Isle of Man is that they rely on a claim about his ancestors made by James, $7^{\text {th }}$ earl of Derby, in his history of Man written during the civil war: "since the reign of Henry VII., of modesty or policy - I know not well which, - they have called themselves only Lords of Man." Clear enough: yet the account contains many inaccuracies, notably the statement that Thomas Stanley was created earl by Edward IV, and James, about to suffer martyrdom for the cause of monarchy, was unlikely to say anything which derogated from its authority. ${ }^{50}$ Some of the other pieces of evidence most frequently cited for the end of the title are also distinctly problematic. It has become usual to claim that a report of May 1551 suggests the earl of Derby had been asked to surrender his title of "lord of Man", for example. This is a letter from Rome recounting what sources in the Low Countries were indicating about the state of English politics. What it specifically says is that the earl of Derby had been asked to renounce his title to the Isle of Man to the king, which is not a challenge to the distinction of king or lord per se, but rather to his ownership of the island. ${ }^{51}$

\footnotetext{
49 "The Provinces and Dominions in the Age of the Wars of the Roses," in Estrangement, Enterprise and Education in Fifteenth Century England, ed. Sharon D. Michalove and A. Compton Reeves (Stroud, 1998), 1-25, esp. 23-5.

${ }^{50}$ Legislation by Three of the Thirteen Stanleys, Kings of Man, ed. W. Mackenzie, Manx Soc., III (1860), 5-6.

${ }^{51}$ Calendar of State Papers, Foreign Series: The Reign of Edward VI., 1547-53, ed. William B. Turnbull (London, 1861), \#370i.
} 
So rather than rely on these dubious foundations for allegedly sudden change, we should consider continuing evidence for kingship and lordship in the Isle of Man into the sixteenth and seventeenth centuries. The survival of the administrative and judicial records of the island in the early sixteenth century is patchy, but although after a break in the records in October 1505 John More and John McCristen appear as justices domini ibidem, in the next sequence of surviving records, in April 1506 we have once again the description of justices domini Regis. As late as October 1538, the deemsters are described as justices domini Regis. From 1543, however, it does appear consistently that the officers are referred to in relation to a lord, and not a king. ${ }^{52}$ There is a similar sense of a possible transition about this time in John Leland's Laboriouse Journey and Serche, a gift to Henry VIII on New Year's Day 1546, published in 1549, which described Man as one of a group of "somtime kingedomes". 53

We should also recognise that the English king's Chancery had for centuries been consistently unwilling to ascribe the title of king to the ruler of Man. Michael Bennett has identified one example of its use of "rex", for Sir William Scrope during the reign of Richard II, but otherwise, "lord" is consistently used. For example, when Luce Macquyn petitioned for a grant of alms in the island in December 1403, he indicated that they were customarily payable by the lords or kings of the island, but the grant which followed stated baldly that the alms were founded by the kings of England and made no reference to the lords of the island. ${ }^{54}$

\footnotetext{
${ }^{52}$ MML, Books of Pleas.

${ }^{53}$ The Laboryouse Iourney and Serche of Iohan Leylande, for Englandes Antiquitees (London, 1549), Eii (my emphasis).

${ }^{54}$ Michael J. Bennett, "English Rule Confirmed: The Isle of Man 1389-1406," in New History of the Isle of Man, vol. III: The Medieval Period, ed. Duffy and Mytum, 170-84, at
} 
Still, a statement of customary law referred to the king of the island in $1577 .{ }^{55}$ And lordship, if that is what it was, retained the most kingly associations. As late as 1691 , the Tynwald ceremony saw the lord appearing on Tynwald Hill seated on a "chaire of state", the governor on his right, the Bishop on his left, and with "the sword of state holden before his Lordship with the point upward". 56

Manuscript copies of the statutes of Man - a key document for those involved in the administration of the island - are usually prefaced by the supposed true chronicle of Man which is essentially a list of kings. Learning the law, or simply looking up a reference, therefore meant leafing through a listing of kings: monarchy literally provided the framework for the increasingly important recording of the law. ${ }^{57}$ We have already noted the significance of the references to Manx kings, as Ree, in the "Traditionary Ballad" at the time of its composition before 1504. The long survival of the ballad in the oral tradition implies no fear,

172, citing TNA, C 270/25/27; TNA, C 81/1401/948 (26 Dec 1403; Calendar of Patent Rolls, 1401-5, 330 (5 Henry IV, p1 m16); Calendar of Documents Relating to Scotland Preserved in Her Majesty's Public Record Office, London, ed. Joseph Bain, iv: 1357-1509, Addenda 1221-1435 (Edinburgh, 1888), \# 643-4).

${ }^{55}$ Jefferson, Lex Scripta, 60-70, at 67-9 (as part of the charge to the great inquest).

${ }^{56}$ HMC, The Manuscripts of Lord Kenyon (London, 1894), no. 778, at 255-8: "The manner of his Lordship's goeing to the Tinwall, from Castle Rushen” (30 July 1691).

${ }^{57}$ MS 09864/21, fols. 1-2 (c. 1667), /22, pp. 1-3 (c. 1755), MML; cf. also MS L.126, fols. 88v-89, College of Arms, London; Vinc. 94, pp. 81-4, College of Arms, London; Stowe MS 1047, fol. 17, British Library (commonplace book of Francis Thynne, Lancaster Herald $1602-$ 8; relating to kings of Man, from John Stowe, and other notes on Man). 
at the very least, among the Manx of associating the lordship with the royal title, whether in relation to Orry or to the more recent Stanleys, in the centuries after 1504.

Even when the Stanleys were in England, they might use the fullest form of their lordly title, as when in 1532 Edward Stanley, in a commission issued from his manor of Colham in Middlesex on 26 June, referred to himself as "Soveraigne and liege Lord of the same Isle". 58 The poetry of the north west of England also tells a different story. In the poem "Flodden Feilde" in the Percy folio manuscript, the title of king is still used. In debate over the performance of north-western forces at the battle, Henry VIII calls for Thomas Stanley: "who will fetch me the king of Man, / the Honnorable Thomas Erle of Darbye?"59 Writing at some time from 1515 to about 1528 in the north west, ${ }^{60}$ the poet was confident that his audience would accept the idea of Henry VIII referring to Stanley as king. And references to courtiers such as Sir William Compton suggest the poet had an acquaintance with the early Henrician court or even that he was recording an eye-witness account; so the poem may just record the use by Henry of the title "king" when addressing Thomas Stanley. ${ }^{61}$ The ballad "The

\footnotetext{
${ }^{58}$ Repeated in agreement of 31 July 1532: Lex Scripta, 30-3, at 30.

${ }^{59}$ Bishop Percy's Folio Manuscript, ed. J. W. Hales and F. J. Furnivall (4 vols, London, 1867-8), i. 320 , ii. $47-58$.
}

${ }^{60}$ David A. Lawton, "Scottish Field: Alliterative Verse and Stanley Encomium in the Percy Folio," Leeds Studies in English n.s., X (1978): 42-57, at 49. The incident is not described in the slightly later "Scottish Field", where the story ends immediately after the battle is won. ${ }^{61}$ Bishop Percy's Folio Manuscript, i. 321, ii. 69-80, etc.. Another major family source, the so-called "Stanley Poem", does not use the title of king and uses of the title "Lord" exclusively; although in it the first earl refers to "my iland": [Thomas Stanley], "The Stanleys antiquytyes in Englishe meeter", MS Rawl. Poet. 13, fols. 12-26v, at fol. 16, Bodleian 
Winning of the Isle of Man, by the Noble Earl of Salisbury”, which was current in the seventeenth century, included an explicit reference the creation of a kingship there, for Montacute. ${ }^{62}$ As late as 1637 , in the poetry of Robert Codrington, Countess Alice, who had been the wife of Earl Ferdinando, was referred to as queen, "Countesse Dowager of Derby and Queene in the Isle of Man". ${ }^{63}$

Others in England around the court believed there was a king in Man: in 1533 the Venetian ambassador explained to his government that there "the Earl of Derby is King, but dependent on [sottoposto a] his Majesty" Henry VIII. ${ }^{64}$ Similarly, the perception abroad continued to be of a royal status - as when the Armada pilot in 1597 described the coasts of the British Isles including Man, where Derby “is called king $[R e y]$ ”. ${ }^{65}$

Library, Oxford (printed in Palatine Anthology: A Collection of Poems and Ancient Ballads Relating to Lancashire and Cheshire, ed. J. O. Halliwell-Phillips (London, 1850), 208-71). ${ }^{62}$ Thomas Deloney, [The Garland of Delight] (London, 1681; STC D945A), cant. 11; also printed in Old Ballads, Historical and Narrative, ed. Thomas Evans (2 vols, London, 1777), i. $277-9$.

${ }^{63} \mathrm{HMC}$, Report on the Manuscripts of the Late Reginald Rawdon Hastings, Esq., of the Manor House, Ashby de la Zouche (4 vols, London, 1928-47), iv. 341-2.

${ }^{64}$ Calendar of State Papers and Manuscripts, Relating to English Affairs, Existing in the Archives and Collections of Venice, and in Other Libraries in Northern Italy, ed. Rawdon Brown, G. Cavendish Bentinck, Horatio F. Brown and Allen B. Hind (38 vols, London, 1864-1947), vol. iv: 1527-1533, 440, item 956.

${ }^{65}$ Albert J. Loomis, “An Armada Pilot's Survey of the English Coastline, October 1597,” Mariner's Mirror 49 (1963): 288-300, at 292. 
The scholars of the late sixteenth and early seventeenth centuries - antiquarian and legal helped to reinforce awareness of the existence of the Manx kingship and its deep historical roots. Camden in 1586 presented the text of the Chronicle of the Kings of Man, and indicated that the crown had passed to Scrope in the fourteenth century, citing Walsingham. Most significantly, he categorically stated that Sir John Stanley received the island and that he and his successors, now earls of Derby, Manniae reguli appellantur. Camden's informant, John Meyrick, bishop of Man between 1576 and 1599, had expressed the opinion to him in 1577 that the island's distinctive language, law and currency were indicators peculiaris dominiiof a distinctive type of lordship. ${ }^{66}$

Sir Edward Coke in his commentary on Calvin's case referred to the "little, but yet ancient \& absolute kingdom of the Isle of Manne". ${ }^{67}$ Michael Drayton described the island in Polyolbion, mentioning "her right successive Kings". ${ }^{68}$ Even John Selden, in some ways the originator par excellence of the idea of English exceptionalism and centralisation played a role in perpetuating the idea of Manx kingship. His view of English distinctiveness did color his account of the Manx kingship in Titles of Honor, published in 1614. Selden was keen to emphasise its limitations, even that sub-kingly titles might have been used in error at times so eager was he to preserve the idea of English difference from a continental Europe which

${ }^{66}$ William Camden, Britannia (London, 1586), 528-42; Cotton Julius MS F. 10, fols. 124-5, British Library (Monumenta, iii. 87-99, at 96).

${ }^{67}$ Edward Coke, La Sept Part des Reports ([London], 1608), fol. 21. Continental European commentators were influenced: André du Chesne, Histoire generale d'angleterre, d'escosse, et d'irlande (Paris, 1614), 20 (the earls call themselves kings “auiourd'huy").

${ }^{68}$ Michael Drayton, Works, ed. J. William Hebel (5 vols, Oxford, 1961), vol. 4: Poly-Olbion, 542. 
had seen the seizure by dukes and counts, originally merely office-holders, of near sovereign regional powers, until strong monarchs seized them back in the late middle ages. For him, the lords of Man were "litle otherwise Kings, then Dukes or Earles are". In spite of this, his account preserved the idea of a kingship in Man, even if it was one he thought had been misunderstood. ${ }^{69}$

Still, Coke and Camden in particular became near canonical in their status as legal, antiquarian and social authorities - and therefore carried the idea of the Manx kingship into the eighteenth century. Then, antiquarians like William Cowper, who had spent time in the island in 1729, could assert confidently that the lord of Man "may not only use the Stile, and title of King, but cause himself to be crown'd such". ${ }^{70}$

Alongside the title, many of the lord's remarkable powers continued unabated. There may have been signs in the appointment by Henry VIII of Henry Man as bishop in 1545 that the English king's authority was to become predominant in that aspect of the government of the island, but under the papacy in Mary's reign Thomas Stanley's appointment bears all the marks of traditional lordship, and on his death Thomas Salisbury found his place in a process which recognised the role of Elizabeth as supreme governor but retained both the form and the reality of the patronage in the hands of the earl of Derby. ${ }^{71}$ Coke was therefore able to

${ }^{69}$ John Selden, Titles of Honor (London, 1614), 31-2.

${ }^{70}$ DCC 9, pp. 16-17, Cheshire Archives and Local Studies, Chester.

${ }^{71}$ Foedera, ed. Thomas Rymer ( ${ }^{\text {rd }}$ edn, 10 vols, The Hague, 1739-45), VI (iii). 132-3, VI

(iv). 141; C. Eubel, Hierarchia catholica medii et recentioris aevi: sive Summorum pontificum, S.R.E. cardinalium, ecclesiarum antistitum series (8 vols, Monasterii, 1913-23), 
refer to the power of patronage as a "visible mark of a kingdome". ${ }^{72}$ The Lord's highly distinctive Admiralty powers also continued: in 1624 the English council's respect for these powers was so great that it was willing to accept delay in negotiations with the French out of respect for them. ${ }^{73}$ And there was also a continuation of the island's position in foreign relations which was noted earlier: as late as 1546, in negotiations leading to the Treaty of Utrecht, Henry VIII was eager to ensure the specific treatment of Man, along with Berwick, Guernsey and Jersey. ${ }^{74}$

There were clearly some limits to these powers. For example, in theory the English parliament had the power to bind Man and the Manx by statute which specifically referred to the island. This was a potentially very significant limitation, were it not for the fact that the English parliament did not in practice pass such an act. Before 1765, the only act directly relating to the Isle of Man was that confirming the title to Earl William and Countess Elizabeth in $1610 .^{75}$ Although the Manx are referred to in some sixteenth-century acts, such

iii. 321; H. C. Cradock, "The Pre-Reformation Bishops of Sodor," Proceedings of the Isle of Man Natural History and Archaeological Society 3 (1925-32): 321-46, at 341.

${ }^{72}$ Edward Coke, The Fourth Part of the Institutes of the Laws of England: Concerning the Jurisdiction of Courts (London, 1797), 282.

${ }^{73}$ Calendar of State Papers Domestic 1623-25, 351. For claims to a ship piratically taken from a Breton in 1538, Letters and Papers Foreign and Domestic of the Reign of Henry VIII, xiii/1. 1027.

${ }^{74}$ Letters and Papers Foreign and Domestic of the Reign of Henry VIII, xxi(1). 8, 71 (p. 29).

${ }^{75}$ Private Act, 7 James I, c. 4: HL/PO/PB/1/1609/7J1n28, Parliamentary Archives, Westminster (Statutes of the Realm (11 vols in 12, London, 1810-28), iv/2. 1154; Monumenta, iii. 114-20). 
as some restricting who could bring wine into English ports, these are pieces of permissive legislation. As such they effectively highlight the difference of the Manx position. They permitted the Manx privileges as an alien and therefore potentially otherwise disadvantaged group. $^{76}$

In a similar way, after the early sixteenth century and for the next two centuries, qualifications to the previous absolute barriers to the involvement of English courts exist but are extremely limited. Even those courts which were otherwise most able to penetrate jurisdictional boundaries, like Star Chamber and Requests, did not see Manx business. The exception is significant: once the English king established an interest in Manx ex-monastic property, Augmentations did, very briefly, deal with Manx business, before that property was definitively alienated - but that is all. ${ }^{77}$

There is, then, a sense that the lord's sovereignty and majesty were beginning to be a little more restricted during the sixteenth century, but there is no sign of a sudden end to subkingship in Man, and it is hard to argue that the English crown became suddenly fundamentally hostile to its expression. If there was a tightening of the approach in some more official media, one trigger for a change in the use of language may have been the "Act

\footnotetext{
${ }^{76}$ A reference to the Manx in England, which is not a true exception to this position, is in the poor law of 1572 (14 Elizabeth I, c. 5 \# 34: referring to "Maniske" vagabonds and beggars of Ireland; Statutes of the Realm, iv/1. 590-8, at 596).

${ }^{77}$ [Kew,] T[he] N[ational] A[rchives of the United Kingdom], E 321/1/96, /3/52 (printed [Edward] Owen, “'Saynt Maholde and Saynt Michell”,, Proceedings of the Isle of Man Natural History and Archaeological Society ns, ii(3) (1923-6): 257-61); Thornton, Cheshire and the Tudor State, 111-15.
} 
for the Ratification of the King's Majesty's Stile", passed in the parliament of 1543-4. For the first time it was laid down in the vernacular what precise words were to be used to describe the king, protected with the penalties of high treason. ${ }^{78}$ This coincides more or less closely with the adoption of conventional naming formulas for the sovereign authority in some local administrative and legal documentation in, for example, the Isle of Man, as it does elsewhere, for example in the Channel Islands. This was the more specific manifestation, in the control of nomenclature of lordship, of that focussing and projection of English royal sovereignty over subordinate jurisdictions which had earlier been expressed most notably in the acts for jurisdiction in liberties (27 Henry VIII, c. 24), and so-called 'Acts of Union' for Wales (27 Henry VIII, c. 26; 34 \& 35 Henry VIII, c. 26), which had the effect, amongst other things, of ensuring that in the areas affected no-one but the king could pardon for treason and felony, or make justices of the peace, and that it was only in his name that judicial writs and indictments would run. ${ }^{79}$

And yet, as this paper has demonstrated, that process could run alongside a continuation of aspects of more extensive lordship in some territories under the control of the English crown, and alongside a continuing use of titles which reflected that lordship. Recent scholarship has suggested continuing strength in traditional franchises, and even innovation, in the extensive and powerful lordships discussed above, such as in the palatinates of Chester and Durham, and in elements of the principality of Wales, and the duchy of Cornwall. ${ }^{80}$ There are several

\footnotetext{
7835 Henry VIII, c. 3 (Statutes of the Realm, iii. 958-9).

${ }^{79}$ Glanmor Williams, Renewal and Reformation: Wales c. 1415-1642 (Oxford, 1993), chapter 11; Peter Raymond Roberts, “The 'Acts of Union' and the Tudor Settlement of Wales" (PhD diss., Cambridge University, 1966).

80 Thornton, Cheshire and the Tudor State, 76-80, 106-18, 125-42, 214-56; Peter R. Roberts, "The English Crown, the Principality of Wales, and the Council of the Marches, 1534-1641", in The British Problem, c. 1534-
} 
reasons why the regal title and its associated rights and paraphernalia survived in Man, and elsewhere. Man was at a key strategic point between England, Scotland and Ireland: so something more was operating than inertia affecting a backwater that might easily be ignored.

It should first be admitted that sarcasm might be the tone in which a Stanley was referred to as king of Man. Especially during the English Civil War and James Stanley's resistance to parliament, his opponents used the title as much as anything to emphasise his isolation and weakness, and his absurdity. At one point late in the earl's resistance to parliament, in 1650, Mercurius Politicus referred to him as King, mentioning that "they say hee hath a Leaden Crown" - which, it alleged, he intended to melt down for bullets to "shoot down that great enemy of Princes, called The Liberty of the people" ${ }^{81}$ But for this to be possible the idea of a king had to be already present in the minds of those who slightingly used it and those who heard and read them.

The power of Manx lordship itself helped support the idea of a royal title. Someone with the power to tax and legislate, with admiralty jurisdiction and so on, was clearly a king. The Isle of Man's distance and difference from the core of the English state - in a time of relatively poor communication and restricted cross-cultural interaction - in very practical terms meant that jurisdiction should be local and largely autonomous.

1707: State Formation in the Atlantic Archipelago, ed. Brendan Bradshaw and John Morrill (Basingstoke, 1996), 118-47; idem, "'A Breviat of the Effectes Devised for Wales', c. 1540-41", Camden Miscellany, xxvi, Camden Soc. $4^{\text {th }}$ ser., 14 (1975), 31-47; Graham Haslam, "Jacobean Phoenix: The Duchy of Cornwall in the Principates of Henry Frederick and Charles", in The Estates of the English Crown, 1558-1640, ed. Richard Hoyle (Cambridge, 1992), 263-96; Thornton, “Fifteenth-century Durham", esp. 87-9, 93-4.

${ }^{81}$ Mercurius Politicus, 8 (Thursday 25 July to Thursday 1 Aug 1650) (The English

Revolution, III: Newsbooks, 5 (31 vols, London: Cornmarket Press, 1971), vol. 1 Mercurius Politicus 1650, 134 modern pagination, 118 old pagination). 
There was a premium on the Manx kingship in English political culture because of the need for the dramatization of difference. Sometimes this served to increase a sense of threat Christopher Marlowe's “Edward II” of 1593 creates Piers Gavaston king and lord of Man. ${ }^{82}$ Michael Drayton's Peirs Gaueston (1594) emphasises the extreme and unusual generosity of Edward through reference to the island:

With bountie now he franckly seales his love,

And to my hands yeelds up the Ile of Man,

${ }^{82}$ The Complete Works of Christopher Marlowe, iii: Edward II, ed. Richard Rowland (Oxford, 1994), 7 (scene 1, 1l. 154ff); Christopher Marlowe, The Troublesome Raigne and Lamentable Death of Edward the Second, King of England: With the Tragicall Fall of Proud Mortimer (London, 1594), [A4v]. The creation is not mentioned in J. S. Hamilton, Piers Gavaston, Earl of Cornwall, 1307-1312: Politics and Patronage in the Reign of Edward II (Detroit, MI, London, 1988), or Pierre Chaplais, Piers Gavaston: Edward II's Adoptive Brother (Oxford, 1994). It is discussed in Colm McNamee, The Wars of the Bruces: Scotland, England and Ireland, 1306-1328 (East Linton, 1997), 58 (1307 to Gavaston, then by 1310 to Bek, who died 1311; then to Henry de Beaumont). At this time Simon de Montacute seems to have attempted to assert his claim, for which he was forgiven in Apr 1313. G. W. S. Barrow, Robert Bruce and the Community of the Realm of Scotland $\left(4^{\text {th }}\right.$ edn, Edinburgh, 2005), 252-3; Seán Duffy, “The ‘Continuation’ of Nicholas Trevet: A New Source for the Bruce Invasion," Proceedings of the Royal Irish Academy, Section C 91 (1991): 303-15, at 305-7. 
By such a gifte his kingly minde to prove, ${ }^{83}$

This is in spite of Marlowe and Drayton's source, in Holinshed's Chronicles, only describing Gavaston's creation as lord, not king. ${ }^{84}$ The arbitrary and extreme nature of Edward's action is pointed up by their deliberate mention of the kingship of Man. For many centuries the royal title in Man fulfilled a need for ways to express what we are, and what the English are especially, in opposition to something we are not.

Finally, and probably most importantly, the political culture of the English at the centre supported the idea of a Manx kingship, as it did other examples of local difference and particular power. This was because political culture was founded on a respect for property and tradition. The mental world of the late middle ages and early modern period possessed many models for strong subordinate authority. These might be found in imperial systems, whether classical or medieval. People in the sixteenth century were increasingly aware of the Anglo-Saxon heptarchy and of Anglo-Saxon relations with other kings, especially through stories like that of Edgar, rowed by kings on the Dee at Chester in $973 .{ }^{85}$ Cheshire antiquaries

${ }^{83}$ Peirs Gaueston Earle of Cornwall: His Life, Death, and Fortune (London, reprinted in The Works of Michael Drayton, ed. J. William Hebel (5 vols, Oxford, 1931-41)), i. 157-208, at 176 (11. 637-9).

${ }^{84}$ Raphael Holinshed, The Firste [-Laste] Volume of the Chronicles of England, Scotlande, and Irelande (2 vols (paginated through), London, 1577), 847.

${ }^{85}$ The kings of Alba, Strathclyde, Mann and North Wales. J. L. Nelson, "Inauguration Rituals," in Early Medieval Kingship, ed. P. H. Sawyer and I. N. Wood (Leeds, 1977), 50-71 (reprinted in her Politics and Ritual in Early Medieval Europe (London, 1986), 283-307, esp. 
could describe "The Kinges of Mertia Pallatines of Chester" in direct succession with the earls of Chester after the Conquest. ${ }^{86}$ There was also an understanding of Celtic kingship (even if in Ireland its forms often concealed a move to realities closer to landlordship), something with which the Stanleys themselves had regular and continuing connections, from their service under de Vere in the 1380s, even through low points of English activity such as the middle of the fifteenth century. ${ }^{87}$ At the Council of Constance, 1414-18, it was a foundation of English claims to status that their king ruled over eight kingdoms (some of which had their own lesser kings), a claim countered by the French mainly on the degree of

299-303); W. H. Stevenson, “The Great Commendation to King Edgar in 973,” English Historical Review xiii (1898): 505-7.

${ }^{86}$ Harleian MS 1988, “Cateralls Book of the Antiquities \& Gentry of Cheshire \&ct”, fols. 7986v, British Library. David Powell wrote from Ruabon on 10 Jan 1591/2, to Sir William Brereton, of a charter which he claimed showed the confirmation of arms of Saxon ancestors of the Breretons of Brereton, Davenports of Davenport, and Duttons of Dutton, in the face of challenges from "some normans newlie Come wt the Conqueror to England" - he had loaned it to "Mr ffoxe" in 1569/70, who had passed it on to one of the earl of Leicester's secretaries, and it was now lost: Harleian MS 1997, fol. 89v, British Library.

${ }^{87}$ While Katharine Simms argues for a change from meaningful kingship to warlordship associated with the concepts of tighearna/dominus, tighearnus, it is evident that the language of kingship remaining current in this context: From Kings to Warlords: The Changing Political Structure of Gaelic Ireland in the Later Middle Ages (Woodbridge, 1987), 21-39; Art Cosgrove, "The Emergence of the Pale, 1399-1447," in A New History of Ireland, vol. II: Medieval Ireland 1169-1534, ed. idem (Oxford, 1987), 539, 573. 
consent entailed. ${ }^{88}$ And English kingship itself was not vested exclusively in the body of the king, but expressed itself also through queens, princes, and more distant members. This was most apparent in the ways in which the king's own children, especially his eldest son, might take on princely roles. The prince of Wales was created with a rod of gold, a coronet (per circulum), and a ring, as well as a kiss and letters of creation. ${ }^{89}$ There had been a wider implication to this in Edward III's use of his kin as princely lieutenants across his "empire". 90 The Stanleys could associate themselves with this after the marriage of Thomas (d. 1504) and Margaret Beaufort in 1472 and even more after that of Henry (d. 1593) and Margaret Clifford in 1555. Margaret's mother Eleanor could be described straightforwardly and regally as "daughter and one of the heires to Charles Brandon Duke of Suffolk \& of Marye the frenche Queene wydowe to king Lewis daughter to kinge Henrye the viith and sister to kinge Henrye the eighthe". ${ }^{91}$

${ }^{88}$ England, Scotland, Wales, Man, and 4 kingdoms of Ireland, with the principality of John, prince of the Orkney Islands: Mansi, Sacrorum conciliorum, xxvii. 1062 (and five languages: English, Welsh, Irish, Cornish and Basque: ibid., 1066).

${ }^{89}$ Chronicle of Adam Usk, 76-7 (Henry son of Henry IV made prince of Wales in 1399). J. L. Laynesmith, The Last Medieval Queens: English Queenship 1445-1503 (Oxford, 2004); Medieval Queenship, ed. John Carmi Parsons (new edn, Stroud, 1998). NB the possession of crowns among the late medieval nobility, although strictly a circlet was the prerogative of dukes alone from the late fourteenth century (and of Robert de Vere as marquess in Ireland) for another 60 years: J. Enoch Powel and Keith Wallis, The House of Lords in the Middle Ages: A History of the English House of Lords to 1540 (London, 1968), 396-7, 419.

${ }^{90}$ W. Mark Ormrod, Edward III (New Haven, CT, London, 2012), 254.

${ }^{91}$ Harleian MS 1997, fols. 78-82v, British Library. 
The use of a royal title in relation to the Isle of Man was therefore a phenomenon which was longer-lasting and wider-ranging in its implications for the power of the island's rulers than has previously been recognised. Nor was it as isolated a phenomenon as the historiography might suggest, since other lords boasted titles indicative of extensive and concentrated lordship of the type to which Rees Davies alerted us. These were men with fiscal, judicial and other rights which were such as to support more intense relationships with those in the areas they ruled, and it is therefore not surprising that a powerful vocabulary of "lordship" and even "kingship" might be used in addressing and describing them, with associated rites, ceremonial and traditions. The traditional contrast between lordship in the territories of the French and English crowns may not, therefore, be as stark as has been thought. The growth of the power of fifteenth-century French princes who ruled "by the grace of god", who wore crowns and regal robes, choreographed their own coronation services and so on has long been widely acknowledged. ${ }^{92}$ The potential for lordly title and its wider implications in the territories of the English crown should not be dismissed as easily as it often has been.

${ }^{92}$ Graeme Small, "The Crown and the Provinces in the Fifteenth Century," in France in the Later Middle Ages, ed. David Potter (Oxford, 2003), 130-54. 